\title{
Fuel cell drive for urban freight transport in comparison to diesel and battery electric drives: a case study of the food retailing industry in Berlin
}

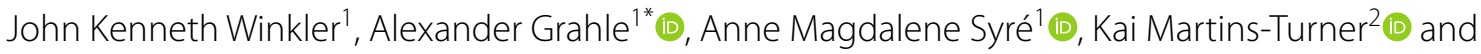

Dietmar Göhlich ${ }^{1}$ (1)

\begin{abstract}
The option of decarbonizing urban freight transport using battery electric vehicle (BEV) seems promising. However, there is currently a strong debate whether fuel cell electric vehicle (FCEV) might be the better solution. The question arises as to how a fleet of FCEV influences the operating cost, the greenhouse gas (GHG) emissions and primary energy demand in comparison to BEVs and to Internal Combustion Engine Vehicle (ICEV). To investigate this, we simulate the urban food retailing as a representative share of urban freight transport using a multi-agent transport simulation software. Synthetic routes as well as fleet size and composition are determined by solving a vehicle routing problem. We compute the operating costs using a total cost of ownership analysis and the use phase emissions as well as primary energy demand using the well to wheel approach. While a change to BEV results in $17-23 \%$ higher costs compared to ICEV, using FCEVs leads to $22-57 \%$ higher costs. Assuming today's electricity mix, we show a GHG emission reduction of $25 \%$ compared to the ICEV base case when using BEV. Current hydrogen production leads to a GHG reduction of 33\% when using FCEV which however cannot be scaled to larger fleets. Using current electricity in electrolysis will increase GHG emission by $60 \%$ compared to the base case. Assuming $100 \%$ renewable electricity for charging and hydrogen production, the reduction from FCEVs rises to $73 \%$ and from BEV to $92 \%$. The primary energy requirement for BEV is in all cases lower and for higher compared to the base case. We conclude that while FCEV have a slightly higher GHG savings potential with current hydrogen, BEV are the favored technology for urban freight transport from an economic and ecological point of view, considering the increasing shares of renewable energies in the grid mix.
\end{abstract}

Keywords: Urban freight transport, Multi agent, Vehicle routing problem, Decarbonization, Fuel cell electric vehicles, Well to wheel, Total cost of ownership

\section{Introduction and motivation}

Commercial road vehicles including buses cause 35.6\% of all greenhouse gas (GHG) emissions in the German

\footnotetext{
*Correspondence: alexander.grahle@tu-berlin.de

${ }^{1}$ Chair of Methods for Product Development and Mechatronics, Technische Universität Berlin, Straße des 17. Juni 135, 10623 Berlin, Germany

Full list of author information is available at the end of the article
}

transport sector. In order to achieve the climate protection goals in this sector, GHG emissions must be reduced through alternative vehicle drive systems [1]. The current focus is on battery electric vehicles (BEV) due to the complete avoidance of local emissions and a comparably high efficiency [2, 3]. However, vehicles powered by Fuel Cell (FC) can be an alternative solution solving several issues of BEV [4]. In addition to locally emission-free driving, fuel cell electric vehicles (FCEV) offer the advantages of 
a short refueling time of only a few minutes and a dieselequivalent range [5]. By converting urban freight transport from ICEV to FCEV, delivery routes, loading and refueling times can be maintained. In contrast, BEVs have range constraints due to the conflict between payload and battery size and require charging times of up to several hours [6]. The question this paper intends to answer is whether these advantages are sufficient to make FCEV advantageous over BEV in decarbonizing urban transport, despite their lower overall efficiency.

\subsection{Technical requirements}

Currently, there are mainly prototypes of FC trucks. These include light 7.5t trucks such as the Fuso Vision F-Cell or heavy-duty semitrailer tractors such as the Nikola Motors Tre, which is expected to be ready for series production by 2023 [7, 8]. According to [9], fuel cells in buses have already reached a lifetime of 25,000 operating hours. This is expected to be sufficient for most trucks to avoid an expensive change of the FC. FC trucks usually store gaseous hydrogen using pressure tanks of type 3 [10] with comparably low pressure of up to 350 bar. Therefore pre-cooling of the hydrogen is unnecessary [11]. There are many ways to produce hydrogen using fossil and renewable energy sources. Today, 54\% of hydrogen in Germany is produced as a by-product of other production processes and $46 \%$ is produced by steam reforming of natural gas [12]. Regenerative hydrogen production can be implemented, for example, with Power-to-Gas (Power To Gas (PtG)) plants [5]. There are currently 86 gas stations in Germany (as of August 2020) for FCEV refueling. Six of them offer hydrogen pressure of 350 bar and are therefore compatible for fuel cell buses and trucks [13].

\subsection{State of research}

Several studies have already examined the conversion from diesel to FC trucks: The "Mobility and Fuel Strategy of the Federal Government" [9] examined the research and development needs of FC trucks. The study carried out a market and technology analysis for Germany. The aim of the model is to test the potential market uptake of alternative drive systems. General conditions such as vehicle class, type of drive, infrastructure, traffic volume and general data such as development of freight traffic or energy scenarios are considered. The model depicts the purchasing decisions of truck operators, taking into account different types of truck usage. The study calculates total cost of ownership (TCO) and well-to-wheel (WTW) emissions for each truck class and drive type. Other studies that consider FCEV for a future market uptake are [14-17]. Yazdanie et al. analyze the WTW emissions and primary energy demand of ICEVs, BEVs, hybrid electric vehicles (HEV), plug-in hybrid electric vehicles (PHEV) and FCEVs of passenger cars considering fossil energy and renewable energy sources [18]. They determine the consumption values per $\mathrm{km}$ for the different types of drive, and the emissions and energy requirements of the different vehicle types. Lombardi et al. present a performance comparison and the ecological effects of four truck classes and the types BEV, ICEV, PHEV and Plug-in FCEV [19]. They use a rule-based and optimized consumption model based on the pontryagin minimum principle. Using two different synthetic drive cycles they calculate the WTW GHG emissions and the WTW primary energy demand using the consumption values. Transport and distribution are taken into account in the WTW path. Lee et al. compare the primary energy consumption and WTW emissions of FCEV and ICEV trucks [20]. A high-resolution longitudinal dynamics model and real vehicle measurements generate the necessary data. For hydrogen production, they consider steam reforming with natural gas and hydrogen as fuel in liquid and gaseous form. Further studies that investigate different hydrogen production paths are [21-26]. Daneberg investigates the potentials of FC trucks, their TCO, hydrogen costs, and the infrastructure required for the Oslo-Trondheim route [27]. The author uses a case study to determine the economically most suitable case depending on hydrogen costs and fleet size. Hall and Lutsey deal with the TCO for zero-emission trucks for the Los Angeles area, California [28]. They investigate the costs and number of hydrogen filling stations for low, medium and high fleet compositions for long-haul tractor-trailers, port drayage, and local delivery trucks. Further studies that investigate the costs of FCEVs are [29-33]. The summary of the current state of research shows that the topic of fuel cell drive has already been investigated in market ramp-up models [9, 14-17], the conversion of car traffic to alternative drive systems [18], the environmental impact of individual vehicles and production paths [19-26, 34], and infrastructure and operating costs of trucks $[27,28]$. However, there is no study that examines the effects of a complete conversion of the entire urban logistics sector to FC trucks. Changes in costs, emissions, and primary energy demand are still pending, especially taking into account the influence of current and future hydrogen production and system prices. Furthermore, to the best of our knowledge, prototype FC trucks have not been used as reference vehicles so far. Martins-Turner et al. use the transport simulation MATSim to investigate the usability of BEVs in comparison to ICEVs for urban freight transport using the food retailing logistics in Berlin as a case study [35]. Changes in transport costs, WTW emissions and primary energy demand of ICEVs and BEVs are computed and compared. 
Since no such study for FCEVs exits so far, the following research question arises: Can FCEVs outperform BEVs in terms of TCO, WTW emissions and primary energy demand when considering a complete decarbonization of urban freight transport?

\section{Methodology}

To find an answer to the research question posed, this study applies the following methodology, which is divided into supply planning, simulation of freight transport, TCO, and well-to-wheel analysis, to the use case of delivering goods to food retailing stores in Berlin.

\subsection{Tour planning}

To deliver food to the various sales locations, nearby distribution centers (so-called "hubs" or "depots") are first supplied. From there the goods are distributed further to the retail stores. Due to its focus on urban transport, this study considers the latter. No data about the actual routes are available. It is furthermore expected that a complete conversion to BEVs or FCEVs will require a rescheduling of routes. Hence, a Vehicle Routing Problem Vehicle Routing Problem (VRP) with a cost-based objective function is solved using the open-source software jsprit [36]. This provides a plan of the delivery routes as well as a certain fleet composition at minimal cost. Real data from the investigation area are used to define the VRP. These are divided into internal and external factors. Internal factors are the location of the hubs and the available vehicle types which differ in variable and fixed costs (determined using TCO) and maximum capacity. External factors include demand for goods, delivery location, and the time windows for delivery. They are taken from [37], which is also the basis of [35]. Also, the transport network and the traffic are external factors that are taken into account.

\subsection{Simulation of freight transport}

To simulate the different cases for urban freight traffic, the openly available, agent-based simulation software MATSim [38] is used. MATSim simulates each vehicle of the transport system as a so-called agent in a transport network, whereby various activities such as receiving and delivering goods are carried out. With this simulation setup, the scenario of urban freight traffic with FCEV can be implemented. In this study the Open Berlin scenario is used to generate background traffic [39]. After 10,000 iterations of the VRP solver, a single MATSim simulation for one day is performed. Subsequently, the costs and calculated fleet composition are examined and the distance and travel times covered by the vehicles are retrieved. The energy demand of the fleets is calculated from the driven distances and the vehicle class specific consumption values which can be found in Table 1 . Using the GHG emissions and primary energy factors multiplied by the hydrogen demand, the total GHG emissions and the energy demand for the different fuels of WTW can be compared.

\subsection{Total cost of ownership (TCO)}

In order to determine the variable and fixed costs for the fleet composition, the life cycle costs are investigated. One method to analyze these costs is the TCO. Fixed costs such as acquisition costs and variable costs such as operating costs of the product are considered [40]. This allows the comparison of the different drive types in terms of operational costs over the product life cycle. In this paper, the TCO method according to the "Bundesverkehrswegeplan 2030" (BVWP, Federal Transportation Plan) [41] is established for FCEV as already done for BEVs and ICEVs in [35]. Four truck classes are considered: light (7.5 tons), medium (18 tons), heavy (26 tons), and heavy (40 tons). For the 40 tons trucks, trailers are included in the cost calculation. The purchase price of the trucks is depreciated half by time and half by kilometers driven. In cost accounting according to BVWP, no insurance costs or other taxes are considered. However, from a supplier's business point of view, these costs are important to consider. Therefore, corresponding values from [42] are used. BEVs and FCEVs are expected to have lower maintenance costs than ICEVs due to fewer components installed. However, there are no sufficient studies proving this assumption yet. Therefore, the maintenance costs from [42] for ICEV are used for all drive classes, therefore most likely overestimation the costs for $\mathrm{BEV}$ and FCEV.

\subsection{Well to wheel analysis (WTW)}

The WTW analysis describes the energy paths of energy carriers from the source to the wheel, distinguishing between Well To Tank (WTT) and Tank To Wheel (TTW). The TTW path accounts for the expended energy and the associated GHG emissions in the steps required to deliver the energy carrier to the vehicle. The ecoinvent 3.6. Cutoff Unit database serves as a basis to model the processes and flows for the WTT analysis of the respective energy carriers [43]. For better comparability of the energy sources from the ecoinvent database and the data from [44], the lower heating value was taken into account as a basis. For BEVs and FCEVs the TTW path equals zero, as no emissions arise due to the energy conversion within the vehicles. For the ICEVs, the energy 
path for a TTW analysis is derived from the consumption values of the trucks and an emission factor for the burned diesel [45]. The GHG emissions and energy use are calculated according to the impact assessment methods IPCC 2013 GWP 100a and Cumulative Energy Demand for lower heating value.

\section{Case study}

This case study is based on [35] in which the food retailing logistics in Berlin is modeled using ICEV and BEV. This study adds FCEV to the scope of observation and combines all results to obtain a holistic perspective. Since the demand model in [35] is based on [37], this study relies on the same model for comparability. Following [37], there are 1057 food markets in Berlin that place approximately 1928 inquiries for goods per day. These inquiries are served by 15 food suppliers (carriers) with 17 distribution centers. The goods are divided into the categories fresh, frozen and dry, which are handled separately. Technically, this leads to 45 carriers that have to be considered in the VRP. The loading time per pallet is approximated with 3 minutes. It is possible that the trucks can be loaded several times at the depots. Not all vehicle sizes are available to all carriers [37]. However, the suppliers have the possibility to select any number of available trucks for their fleet.

\subsection{Vehicle parameters}

In this study, the five different cases shown in Fig. 1 are analyzed. First, the current state is modeled as a reference. For this purpose, four types of ICEVs in the dimensions $7.5 \mathrm{t}, 18 \mathrm{t}, 26 \mathrm{t}$ and $40 \mathrm{t}$ are considered. Subsequently, two cases are considered for the BEV. Martins-Turner et al. show that today a BEV excluding battery costs about 1.6 times as much as a complete ICEV [35]. However, it is assumed that in the future a BEV without a battery will cost the same as an ICEV. These are the two case distinctions for vehicle costs (BEV160 and BEV100). In this study it is assumed that BEV160 represents today's market and will therefore be operated with today's electricity mix. In contrast, BEV100 represents a future scenario and is therefore operated with an electricity mix of $50 \%$ wind and $50 \%$ solar power. BEVs are designed in the same weight classes as the ICEVs. The batteries are dimensioned in such a way that, taking into account the increased permissible total mass for emission-free commercial vehicles in the EU [46], there is no change in payload compared to ICEVs. Lithium nickel manganese cobalt oxides (NMC) commercial vehicle batteries with a price of $600 / \mathrm{kWh}$ on pack level are used. All other specifications for the first three cases can be viewed in [35]. The novelty in this study are the two cases with FCEV. The layout of FCEV is equivalent to BEV, but with a smaller battery and the FC and tanks as additional components. Therefore the cases FCEV160 and FCEV100 are defined analogously to the BEV cases. As there are

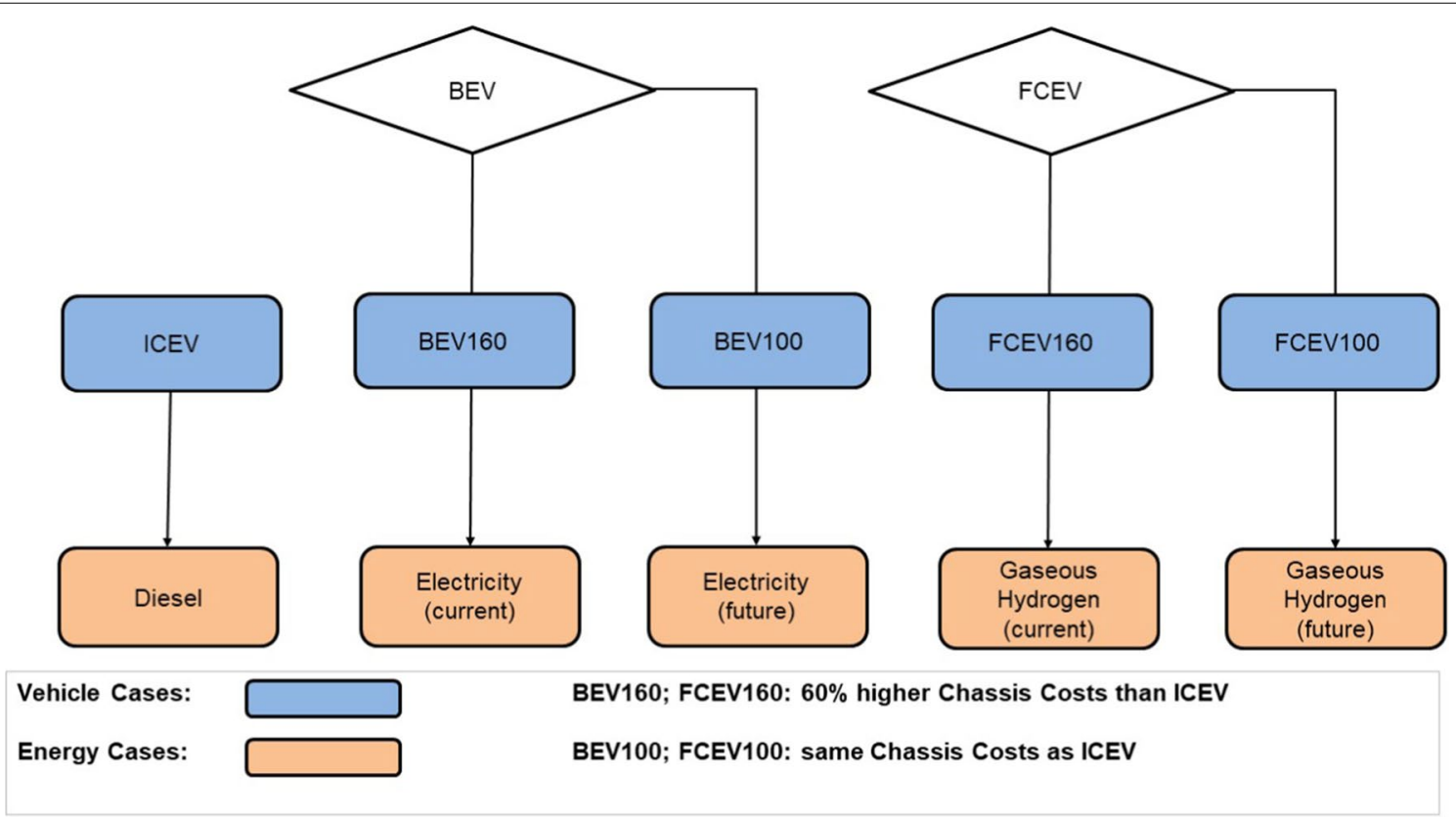

Fig. 1 Overview of vehicle and fuel scenarios 
currently no FC trucks in series production, the Nikola Tre [8] for the 40t truck, the prototype from the partner project ASKO Scania [47] for the 26t truck and the concept truck Fuso Vision F-Cell [7] for the light 7.5t truck are selected as reference models. FCEV prototypes for the medium 18t truck are still pending, therefore separate assumptions are made. FCEVs have an approximately 1.8 times higher TTW consumption due to the energy conversion in the FC for which an efficiency of $55 \%$ is assumed according to [19]. According to Kurzweil the FC of a vehicle is mostly kept at an optimal operating point and the remaining power is provided by a battery [48]. Thus the consumption value of the $18 \mathrm{t}$ truck can be calculated with the consumption value of the BEV in the same weight class divided by a fuel cell efficiency of $55 \%$ [19]. The consumption values for the $7.5 \mathrm{t}$, the $26 \mathrm{t}$ and the $40 \mathrm{t}$ truck result from the range and stored energy in the form of hydrogen indicated in $[7,8,47]$. The values appear plausible, as similar values result with the aforementioned calculation method. For all FCEV classes, the same system power as in the BEV case is assumed in order to be able to compare them fairly. In FCEV, the system performance is made up of the power of the fuel cell and the battery. The hydrogen tank of the 18 tons FCEV is dimensioned to achieve a similar range as for ICEVs. For the FCEV cases, the vehicle configurations in Table 1 result. The simulation results in Fig. 2 shows that the assumed ranges of the FCEVs are sufficiently high for all truck classes so no intermediate refueling is needed.

\subsection{Cost parameters}

\subsubsection{Vehicle prices}

Since the construction of BEV and FCEV are very similar except for fuel cell and tank, the same chassis costs

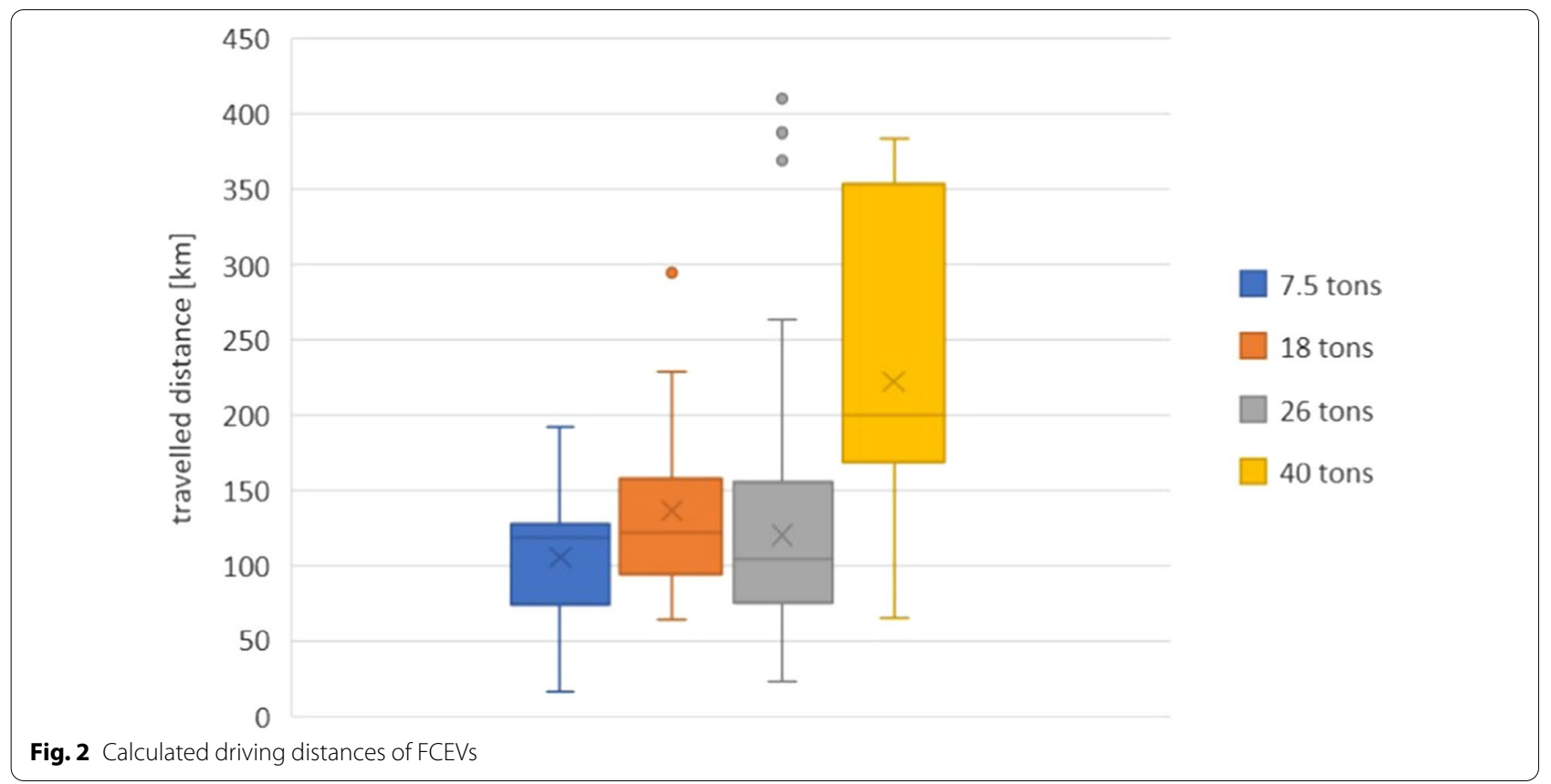

Table 1 Vehicle specifications of FCEV classes

\begin{tabular}{lllll}
\hline $\begin{array}{l}\text { FCEV class } \\
\text { Comparable models }\end{array}$ & $\begin{array}{l}\mathbf{7 . 5} \text { tons } \\
\text { Fuso Vision F-Cell }\end{array}$ & $\begin{array}{l}\mathbf{1 8} \text { tons } \\
-\end{array}$ & $\begin{array}{l}\mathbf{2 6} \text { tons } \\
\text { ASKO Scania FCT }\end{array}$ & $\begin{array}{l}\mathbf{4 0} \text { tons } \\
\text { Nikola Motors Tre }\end{array}$ \\
\hline Range $[\mathrm{km}]$ & 300 & 500 & 500 & 800 \\
Energy consumption $[\mathrm{kWh} / 100 \mathrm{~km}]$ & 111 & 193 & 275 & 333 \\
System power $[\mathrm{kW}]$ & 210 & 305 & 370 & 440 \\
Fuel cell power [kW] & 75 & 80 & 90 & 120 \\
Battery power $[\mathrm{kW}]$ & 135 & 225 & 280 & 320 \\
Hydrogen fuel $[\mathrm{kg}]$ & 10 & 29 & 33 & 80 \\
Battery capacity $[\mathrm{kWh}]$ & 40 & 50 & 56 & 70 \\
\hline
\end{tabular}


presented in [35] are assumed for both vehicle types. It is assumed that the chassis costs for FCEV are currently $60 \%$ higher than for ICEV (Case: FCEV160) and are expected to be the same as for ICEV in the future (Case: FCEV100). The cost factors hydrogen tank, fuel cell and battery are included in the purchase price of the FCEV in addition to the chassis costs. Specific costs for compressed gas tank, fuel cell and battery are assumed to be $36.68 / \mathrm{kWh}$ storable hydrogen, $205 / \mathrm{kW}$ engine power and $600 / \mathrm{kWh}$ battery capacity $[35,49]$. Table 2 shows the cost structure for all cases.

The lifetime of the fuel cell is critical for trucks, because they are exposed to a longer daily operation compared to passenger cars. Since in jsprit every vehicle is assigned to a specific driver and the drivers are only allowed to work $8 \mathrm{~h}$ per day according to german law, $8 \mathrm{~h}$ is the longest possible FC operating time per day. Assuming 250 working days per year and a vehicle lifetime of 11 years, a maximum fuel cell lifetime of $22,000 \mathrm{~h}$ is required. The assumption of $25,000 \mathrm{~h}$ is therefore sufficient [9]. The wage costs for the drivers are covered by [41].

\subsubsection{Infrastructure and hydrogen prices}

This study is based on the assumption that the infrastructure to provide hydrogen is available. This contradicts the present situation described in the introduction with 6 capable gas stations, but is a mandatory prerequisite for a complete conversion to FCEV. It is assumed that FCEVs start their delivery routes with a full tank. Refueling times are considered negligible compared to necessary loading times at the depots. Accruing infrastructure costs are not examined in detail within the scope of this study, but are integrated in the assumptions of hydrogen prices. For the FCEV160 case, which assumes the current state of the art and current prices, a hydrogen price of 13.23/ $\mathrm{kg}$ is assumed. This results from the case " 0.1 million FCEV" from [5] where the hydrogen is transported by trucks. This study assumes a hydrogen production mix of about $50 \%$ by-products of the chemical industry and $50 \%$ natural gas reformation according to [5]. For the future FCEV100 case the hydrogen price is set to $7.13 / \mathrm{kg}$. This price results from the scenario " 20 million FCEV" from [5], in which pipelines and trucks transport the hydrogen. The hydrogen is produced exclusively by electrolysis using renewable energies.

\subsection{Well-to-tank parameters}

For the base case and the two BEV cases the values from [35] were updated. For the FCEV cases different production mixes are assumed for today and the future. All emission factors can be seen in Table 3. In Germany, a mixture of diesel with a maximum of $7 \%$ biodiesel is permitted according to DIN EN 590 [50]. The energy and emission factors of this diesel mix are taken from DIN EN 16258 [45]. The German electricity mix in ecoinvent is updated per share of production according to [51] for 2019 and expanded to include the production process using photovoltaics (see Fig. 3). The flows in ecoinvent are scaled proportionately or supplemented by individual flows from the database. In addition, a future energy mix (Electricity (future)) of 50\% wind and 50\% solar energy is defined as in [52]. The processes of electricity generation in Germany are accordingly adopted from ecoinvent.

The WTT consideration for hydrogen is divided into two cases: Gaseous Hydrogen (current) and Gaseous Hydrogen (future). The current case consists of the production methods according to the current status as shown in [12] as follows: $46.15 \%$ steam reforming from natural gas; $19.23 \%$ gasoline reforming; $27.69 \%$ ethylene production, $6.92 \%$ chlor-alkali electrolysis (see Fig. 4).

Table 2 Cost parameters for vehicle types

\begin{tabular}{|c|c|c|c|c|c|c|}
\hline Vehicle type & Cost type & Base: ICEV & BEV 160 & BEV 100 & FCEV 160 & FCEV 100 \\
\hline \multirow[t]{3}{*}{7.5 tons } & Fixed [/day] & 63.49 & 81.04 & 74.76 & 80.91 & 74.63 \\
\hline & Variable per distance [/km] & 0.4 & 0.51 & 0.46 & 0.81 & 0.56 \\
\hline & Variable per time [/h] & 17.64 & 17.64 & 17.64 & 17.64 & 17.64 \\
\hline \multirow[t]{3}{*}{18 tons } & Fixed [/day] & 80.47 & 107.43 & 96.26 & 109.29 & 98.13 \\
\hline & Variable per distance [/km] & 0.65 & 0.61 & 0.55 & 1.15 & 0.74 \\
\hline & Variable per time [/h] & 17.64 & 17.64 & 17.64 & 17.64 & 17.64 \\
\hline \multirow[t]{3}{*}{26 tons } & Fixed [/day] & 82.6 & 132.14 & 119.6 & 114.96 & 102.41 \\
\hline & Variable per distance [/km] & 0.67 & 0.76 & 0.72 & 1.46 & 0.92 \\
\hline & Variable per time [/h] & 17.64 & 17.64 & 17.64 & 17.64 & 17.64 \\
\hline \multirow[t]{3}{*}{40 tons } & Fixed [/day] & 126.58 & 192.8 & 183.93 & 170.94 & 162.07 \\
\hline & Variable per distance [/km] & 0.69 & 0.8 & 0.78 & 1.67 & 1.04 \\
\hline & Variable per time [/h] & 20.124 & 20.124 & 20.124 & 20.124 & 20.124 \\
\hline
\end{tabular}




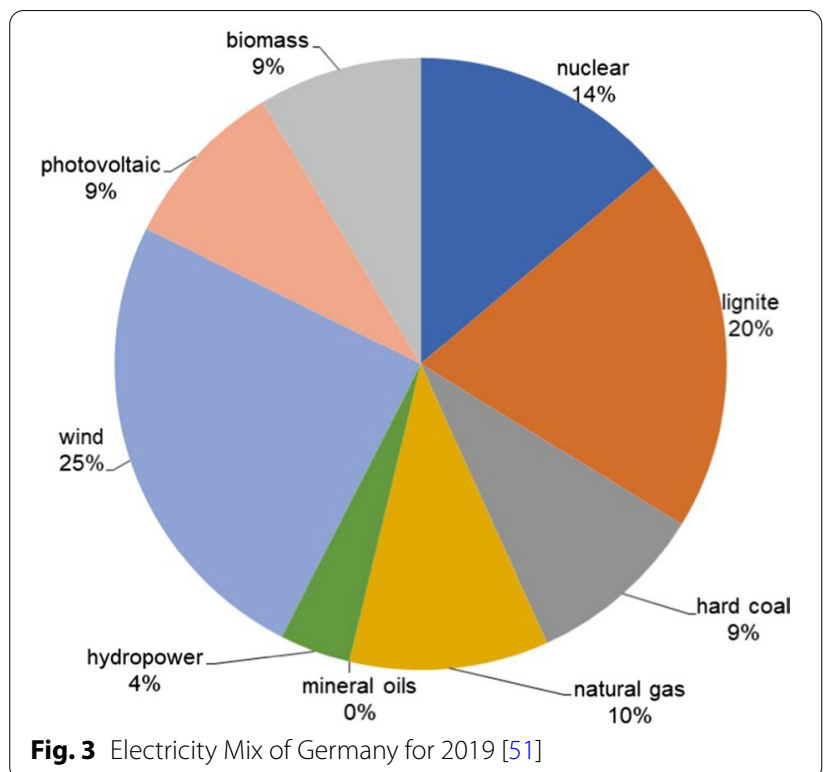

The process for steam reforming from natural gas is taken from the JRC study and included in our calculations [44]. In this case it is assumed that a central upscaled reformer is used, natural gas is transported by pipeline to Europe, compressed and distributed to the retail market [44]. The other manufacturing processes for the German site are taken from ecoinvent 3.6. Cutoff Unit.

As a sensitivity analysis, a second case is calculated for today's hydrogen, which assumes that the hydrogen is produced entirely by high temperature electrolysis using today's electricity. This also serves for a better comparison with the current BEV scenario. For the efficiency of the high temperature electrolysis, a range between $65 \%$ and $85 \%$ is specified according to [53]. For simplification, the costs for this path are not changed compared to today's market price. This is not unrealistic (although somewhat low), but no real-world values are available, since high temperature electrolysis does not yet play a role in commercial hydrogen production.

The potential to produce large amounts of hydrogen from renewable energy sources in Germany is limited due to the space needed to build wind turbines or solar parks. One possible solution is $\mathrm{PtG}$, which are ideal at locations with adequate available space and wind or sunshine [5]. The renewable electricity is directly usable in electrolysers to produce hydrogen. The future case consists of $50 \%$ electrolysis with wind power and $50 \%$ electrolysis with solar power (see Fig. 4). The electricity generated by offshore wind turbines is used to produce hydrogen which is then distributed by pipelines to the filling stations. For generating electricity from offshore wind turbines the

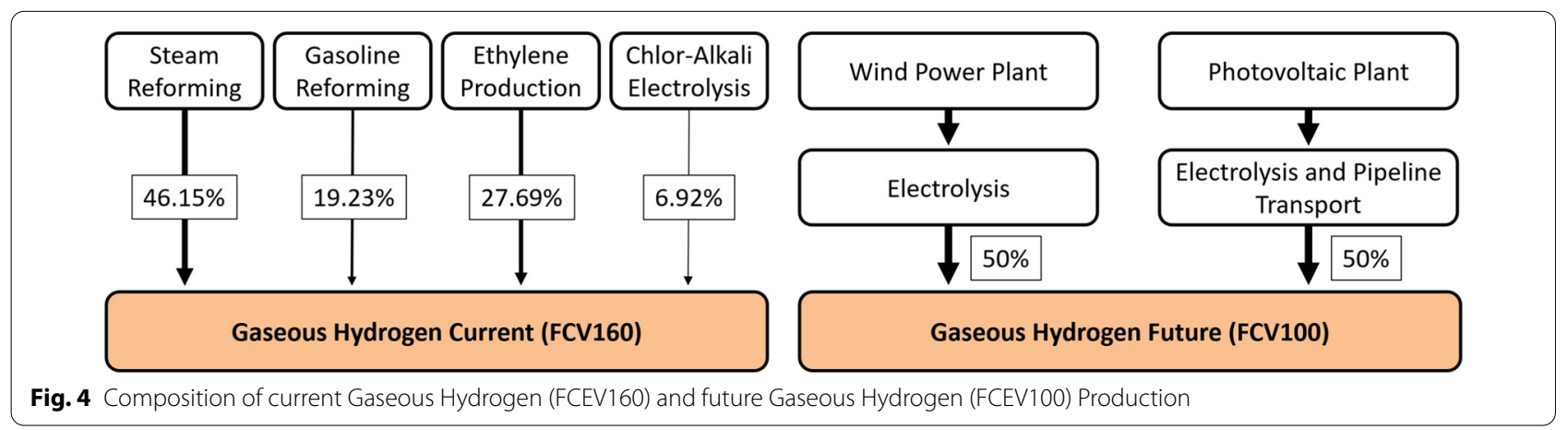

Table 3 Well-to-tank energy and emissions factors

\begin{tabular}{lll}
\hline Energy carrier & Well-to-tank & Emissions factor \\
\cline { 2 - 3 } & Energy factor & $\begin{array}{c}\text { [kg CO2eq/ } \\
\text { kWhIEnergyCarrier] }\end{array}$ \\
\hline Diesel & {$[\mathbf{k W h / k W h E n e r g y C a r r i e r ] ~}$} & 0.318 \\
Electricity (current) & 1.25 & 0.522 \\
Electricity (future) & 2.45 & 0.057 \\
Gaseous Hydrogen (current) & 1.30 & 0.258 \\
Gaseous Hydrogen sensitivity (current electricity, $\eta=85 \%)$ & 2.88 & 0.61 \\
Gaseous Hydrogen (future) & 2.42 & 0.103 \\
\hline
\end{tabular}


process from ecoinvent is used. Subsequent processes such as electrolysis, power distribution and compression on the retail side are taken from [44] and included in our calculations. The energy required for these processes results from the future energy-mix (Electricity (future)). As regions like North Africa have sunny days almost all year round, there is a high potential for power-to-gas plants. The electricity generated by photovoltaic systems can then be used directly to produce hydrogen. In this study it is assumed that $50 \%$ of future hydrogen will be produced in this way. Therefore, the power generation process from ecoinvent and the intermediate steps from [44] are used. According to [54] it is possible that, in addition to natural gas pipelines that have already been laid from North Africa to Europe, hydrogen pipelines could be added to the existing pipelines. It is assumed that the hydrogen will then be transported to Germany via a $4000 \mathrm{~km}$ long pipeline.

\section{Results}

The results of the simulations are divided into TCO, WTW emissions and primary energy consumption of the fleets. The fleet composition which results from solving the VRP for the different cases can be seen in Fig. 5. It is noticeable that the 26 tons trucks make up the largest share of all truck classes with $73-79 \%$. It should also be mentioned that the BEV cases require between 1.5 and $3 \%$ less vehicles than the ICEV and FCEV cases.

Figure 6 shows the resulting driving times and distances of the entire truck fleet for all cases. In comparison to the ICEV case, both BEV cases have 1.5-1.9\% longer travel times and 1.6-2.7\% additional distances for the entire truck fleet.

The total costs of the fleet of all carriers per day and per technology are divided into fixed, time and distance variable costs (see Fig. 7). The daily costs of the entire ICEV fleet of all carriers amount to 66,997 /day consisting of fixed costs (24,204 /day), time variable (18,593 /day) and distance variable $(24,200 /$ day $)$ costs. The total costs for the BEV cases are 82,751/day (BEV160) and 78,318/day (BEV100), which translates into an increase of $23.5 \%$ and $16.9 \%$ compared to the ICEV case. This is mainly driven by the fixed costs for BEVs, which are 38 to $49 \%$ higher than those for ICEV because of the high battery price. These also influence the distance variable cost. Since procurement costs are depreciated half by time and half by distance, the high system prices result in a slight increase of $1.6 \%$ and $2.7 \%$ compared to the base case despite the high efficiency of the powertrain. Also, the time variable costs for both BEV cases are slightly higher at $2 \%$ due to the slight increase in total travel time. The total daily costs of the FCEV cases are 105,336 /day (FCEV160) and $82,271 /$ day (FCEV100) which amounts to an increase of $56.6 \%$ and $22.3 \%$ compared to the base case. The distance variable costs are the largest part with 53,111 /day (FCEV160) and 33,369/day (FCEV100). They are 119\% and $38 \%$ higher compared to the ICEV case. This results mainly from the high hydrogen prices. In addition, the fixed costs for FCEV of 33,375/day (FCEV160) and 30,052 /day (FCEV100) result in an increase of $25 \%$ and $38 \%$ compared to the base case. Figure 7 shows the absolute costs for all considered cases.

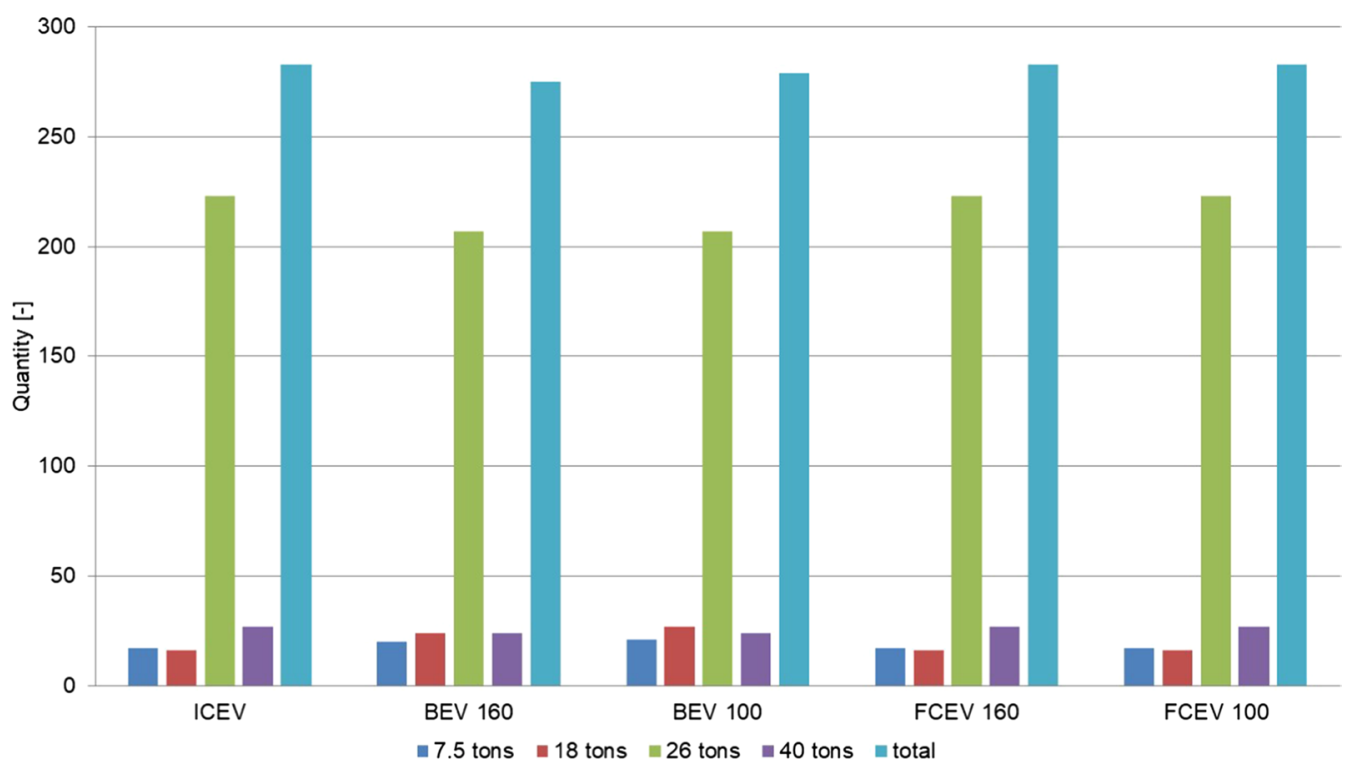

Fig. 5 Resulting fleet composition 

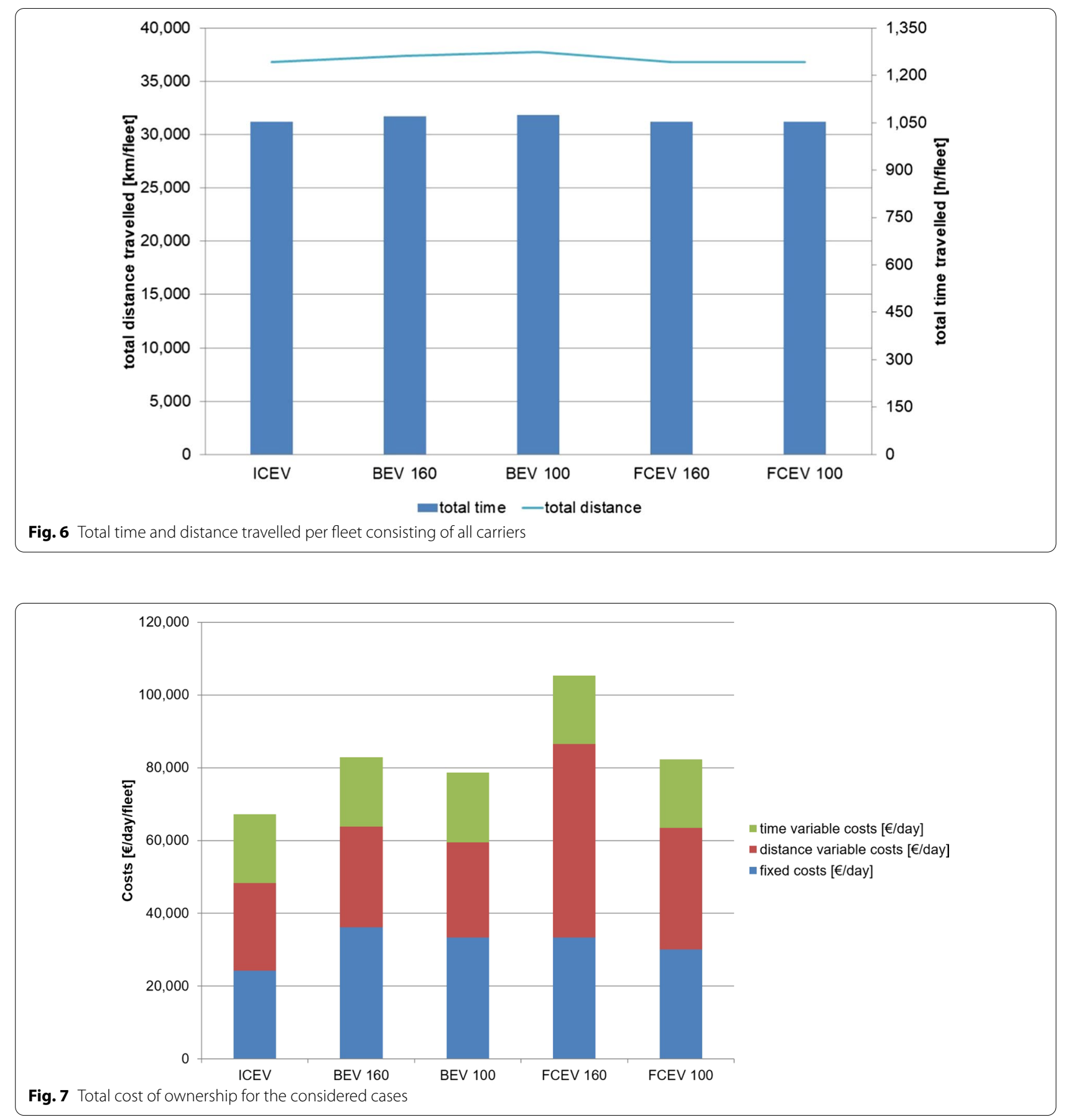

Figure 8 shows the WTW CO2 equivalent emissions per year of the entire fleet for all cases. As mentioned before, a distinction is made between electricity produced according to the current production process and electricity from $100 \%$ renewable energy sources. Hydrogen according to the current production mix, electrolysis using the current electricity mix and produced using $100 \%$ renewable energies is considered. The GHG emissions for the ICEV case amount to 9572tCO2eq/a. 7151tCO2eq/a result for the BEV case with the current German electricity mix, (BEV160). This is a $25 \%$ reduction of GHG emissions compared to the ICEV case. Considering a future electricity mix of $100 \%$ renewable electricity, the GHG emissions drop to $774 \mathrm{tCO} 2 \mathrm{eq} / \mathrm{a}$ (BEV100). Compared to the base case, this is a reduction of $92 \%$. The WTW emissions of the FCEV fleet with 


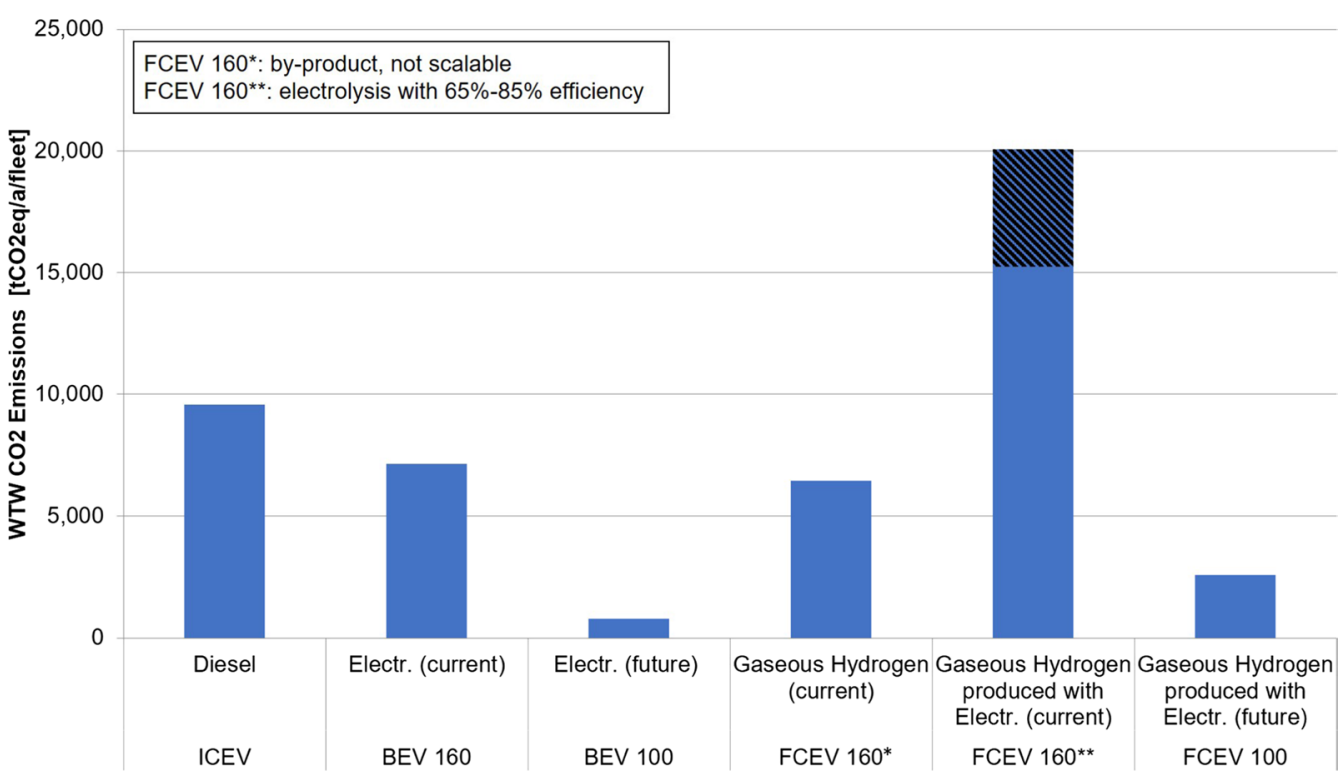

Fig. 8 WTW CO2 emissions of entire fleet with various energy sources

a current hydrogen mix are 6442 t CO2eq/a. This corresponds to a $33 \%$ reduction in GHG emissions compared to the ICEV case. However, the sensitivity analysis results in $15.338 \mathrm{tCO} 2 \mathrm{eq} / \mathrm{a}$ ( $85 \%$ electrolysis efficiency) for hydrogen from the current electricity mix, which is a $60 \%$ increase in emissions compared to the ICEV case. If the FCEV fleet is operated with a $100 \%$ renewable hydrogen mix (FCEV100), the result is 2,580tCO2eq/a. This represents a $73 \%$ reduction in emissions compared to the ICEV case.

Figure 9 shows the primary energy demand per year for all cases. All primary energy factors used are shown in Table 3 . The primary energy demand for the ICEV case with $37,680 \mathrm{MWh} / \mathrm{a}$ is the basis for comparison. The primary energy demand for the BEV case with the current electricity mix is 33,562 MWh/a (BEV160). Compared to the ICEV case, this is about $11 \%$ less primary energy.

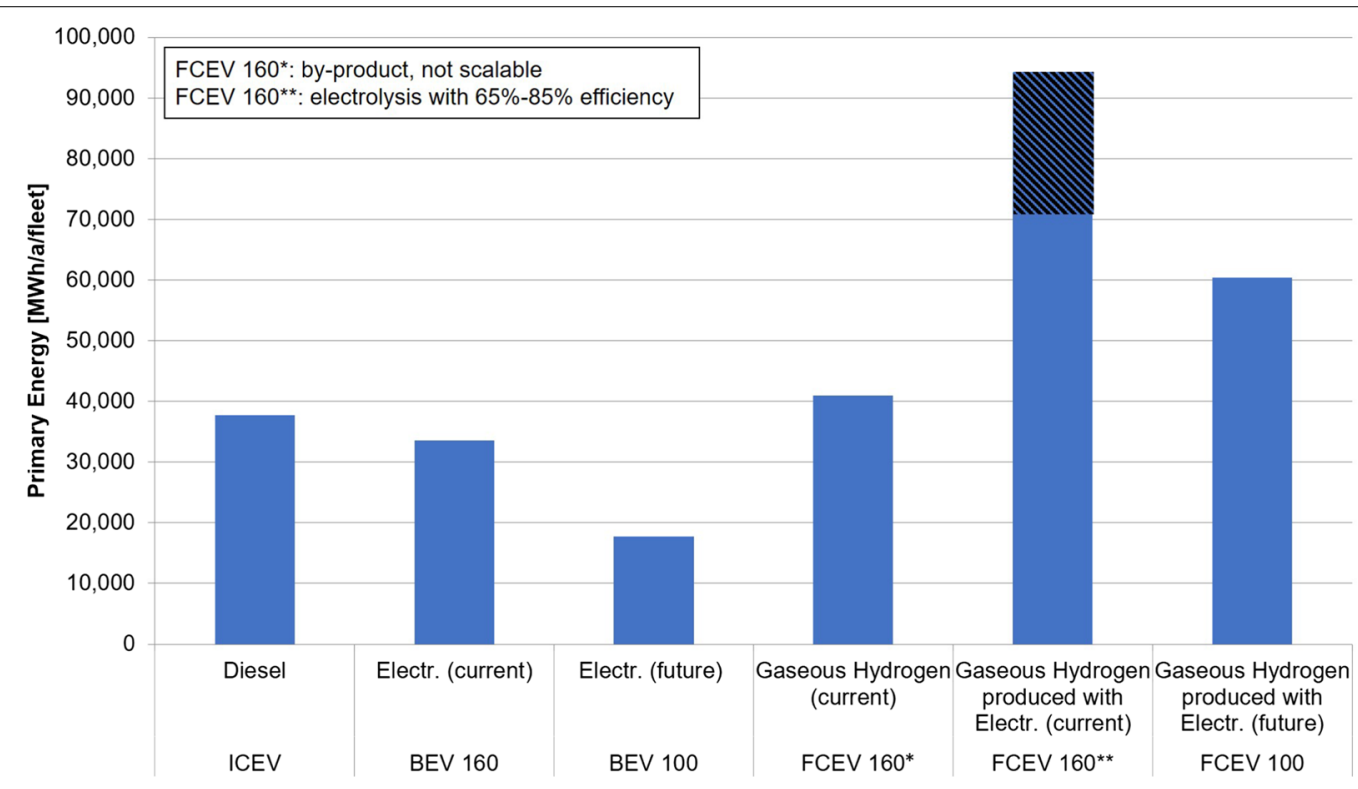

Fig. 9 Primary energy demand of entire fleets with various energy sources 
With an electricity mix of $100 \%$ renewable electricity, $17,715 \mathrm{MWh} / \mathrm{a}$ (BEV100) is required. This corresponds to a $53 \%$ reduction in primary energy demand. Considering the entire FCEV fleet, the primary energy requirement is $40,960 \mathrm{MWh} / \mathrm{a}$ with the current hydrogen mix, $71,989 \mathrm{MWh} / \mathrm{a}$ for the hydrogen produced using the current electricity mix and 60,441 MWh/a with the hydrogen mix from renewable energies. As a result, the FCEV160 case requires 9\% more primary energy with the current hydrogen mix compared to the base case while in the FCEV100 case $60 \%$ more primary energy is needed. The sensitivity case shows an increase by more than $90 \%$ compared to the ICEV base case.

\section{Discussion}

\subsection{Validation of the parameters}

\subsubsection{TCO}

The investment costs are crucial for the fixed costs. Gnann et al. [9] present with 696,070 investment costs for a heavy-duty semi trailer higher values for FCEVs than this work (40 tons FCEV: 274,004 (FCEV160) and 232,904 (FCEV100)). Danebergs [27], however, calculates investment costs of only 179,996 (2020) and 126,597 (2030) for heavy-duty semi trailer tractors (converted at an average exchange rate in 2018: 9.6073NOK $=1$ [55]). After all, these values are all based on individual assumptions, e.g. for fuel cells, tank, battery or glider costs and should therefore be viewed critically. Actual investment costs will be available after the launch of series production of FCEVs. Since fuel consumption for trucks accounts for a large proportion of operating costs, it is important for cost considerations. The fuel consumption for 3.5-7.5 t heavy FCEVs of $94-109 \mathrm{kWh} / 100 \mathrm{~km}$, for $>12 \mathrm{t}$ FCEVs $129-201 \mathrm{kWh} / 100 \mathrm{~km}$ and for semi trailer tractors $225-262 \mathrm{kWh} / 100 \mathrm{~km}$ from [9] are similar to the assumptions in this study (see Table 1). Gnann et al. [9] calculate TCO for FCEV $<12$ t for 2030 of 30,000/a at a driving performance of $35,000 \mathrm{~km} / \mathrm{a}$, whereby no wage costs are included. They assume hydrogen prices from [29], which take into account production costs and distribution costs. For similar mileage, however, this study calculates 42,618/a for 7.5t FCEV (FCEV100). This includes 9,232/a wage costs. The annual TCO for 2020 in [28] for Drayage Trucks (equivalent to 26 tons truck class) ranges from 44,670/a to 51,817/a and for 2030 from 31,269/a to $34,843 / \mathrm{a}$. The costs for fossil hydrogen are $4.57 / \mathrm{kg}$ and $3.73 / \mathrm{kg}$ in 2020 and 2030 respectively and $8.27 / \mathrm{kg}$ and $6.15 / \mathrm{kg}$ for regenerative hydrogen. In this study the costs are 89,753/a (FCEV160) and 70,652 /a (FCEV100) for 26 tons FCEV. However, to accurately model the effects of more or less tours, this study includes labour costs, which leads to cost differences. Additionally, the assumed hydrogen prices of $13.23 / \mathrm{kg}$ and $7.13 / \mathrm{kg}$ contribute to the difference. Besides the different hydrogen prices, a lower consumption of $152.28 \mathrm{kWh} / 100 \mathrm{~km}$ for Drayage Trucks in [28] leads to lower operating costs. The assumed hydrogen price in this study includes production costs and investment costs for filling stations, transport and distribution for hydrogen as fuel. Hall and Lutsey [28] give no reference or explanation for the assumption of hydrogen costs. The infrastructure costs are given separately.

\subsubsection{WTW-GHG emissions}

Gnann et al. [9] assume GHG emissions (WTW) of $0.324 \mathrm{kgCO} 2 \mathrm{eq} / \mathrm{kWh}$ for diesel. In this study diesel with $7 \%$ biodiesel content is assumed which results in $0.318 \mathrm{kgCO} 2 \mathrm{eq} / \mathrm{kWh}$ [45]. In [19], the Italian electricity mix with $0.410 \mathrm{kgCO} 2 \mathrm{eq} / \mathrm{kWh}$ and a fully renewable electricity mix with $0 \mathrm{kgCO} 2 \mathrm{eq} / \mathrm{kWh}$ are assumed. [9] assume $0.202 \mathrm{kgCO} 2 \mathrm{eq} / \mathrm{kWh}$ for 2030 . In this study, however, the actual electricity mix from 2019 in Germany is used which results in $0.522 \mathrm{kgCO} 2 \mathrm{eq} / \mathrm{kWh}$. In renewable electricity production emissions occur i.a. due to the construction of the respective plants. Therefore we consider $0.057 \mathrm{kgCO} 2 \mathrm{eq} / \mathrm{kWh}$ for the electricity from $100 \%$ renewable sources. [9] assume $0.306 \mathrm{kgCO} 2 \mathrm{eq} /$ kWh (WTW) for hydrogen with production by electrolysis and an average electricity mix for 2030. [19] assume three hydrogen paths: Hydrogen production with coal gasification combined with $\mathrm{CO} 2$ sequestration, steam reforming of natural gas and electrolysis with $100 \%$ renewable energies. This results in $0.200 \mathrm{kgCO} 2 \mathrm{eq} / \mathrm{kWh}$, $0.407 \mathrm{kgCO} 2 \mathrm{eq} / \mathrm{kWh}$ and $0 \mathrm{kgCO} 2 \mathrm{eq} / \mathrm{kWh}$ respectively. In this study, however, the current hydrogen mix consists of approx. $50 \%$ by-products and $50 \%$ steam reforming. This results in $0.258 \mathrm{kgCO} 2 \mathrm{eq} / \mathrm{kWh}$. Yazdanie et al. show 0.076 and $0.144 \mathrm{kgCO} 2 \mathrm{eq} / \mathrm{kWh}$ for hydrogen production with electrolysers and electricity from photovoltaic plants and wind [18]. This is $0.110 \mathrm{kgCO} 2 \mathrm{eq} / \mathrm{kWh}$ with a mix of $50 \%$ wind and $50 \%$ solar energy, which is comparable to this study with $0.103 \mathrm{kgCO} 2 \mathrm{eq} / \mathrm{kWh}$. However, in [18] no emissions due to transport and distribution were considered.

\subsubsection{WTW-Primary energy demand}

In this study, the energy requirement for diesel, at 1.25 $\mathrm{kWh} / \mathrm{kWhEnergyCarrier,} \mathrm{is} \mathrm{3 \%} \mathrm{higher} \mathrm{than} \mathrm{in} \mathrm{[19],}$ which can be explained by the $7 \%$ biodiesel content, that requires more primary energy than conventional diesel. According to [19], the energy requirement for the Italian electricity mix is $2.86 \mathrm{kWh} / \mathrm{kWhEl}$, which is $16 \%$ higher than the German electricity mix for 2019. This is due to the fact that Germany has been able to increase its share of renewable electricity to $40 \%$. In this study the 
primary energy requirement for renewable electricity is $1.30 \mathrm{kWh} / \mathrm{kWhEl}$ (see Table 3), which is $10 \%$ higher than in [19] where $100 \%$ efficiency and only losses due to electricity distribution are considered for renewable electricity generation. According to [19], the energy demand for fossil hydrogen is between $2.18-2.76 \mathrm{kWh} / \mathrm{kWhH} 2$. In this study, however, an energy requirement of $1.64 \mathrm{kWh} /$ $\mathrm{kWhH} 2$ is considered. The lower energy demand is due to the fact that more than $50 \%$ of the hydrogen is produced as a by-product. In the sensitivity case the primary energy factor is with a value of $2.88 \mathrm{kWh} / \mathrm{kWhH} 2$ even higher than the one presented in [19]. If renewable electricity is used to produce hydrogen, the primary energy requirement increases to $2.55 \mathrm{kWh} / \mathrm{kWhH} 2$ in [19]. In [18], hydrogen production with electrolyzers and electricity from photovoltaic systems and wind requires 1.8 - 2.6 and $1.5-2.1 \mathrm{kWh} / \mathrm{kWhH} 2$. The energy demand for hydrogen from renewable energies in this study is with $2.42 \mathrm{kWh} / \mathrm{kWhH} 2$ in a realistic range, since the energy demand for transport and distribution was considered additionally.

\subsection{Evaluation of results}

When considering BEV or FCEV for the total decarbonization of food supply in urban traffic the former is to be prefered. From a cost point of view, FCEVs have higher operating costs due to the price of hydrogen and similarly high investment costs. The advantage of a diesel-equivalent range and refueling time of FCEV is decisive for the decision of the preferred technology, if refueling is necessary to complete the delivery route. However, in the use case at hand the BEVs can reach $56 \%$ of all destinations without intermediate charging and $90 \%$ with one-time intermediate charging [35]. With additional public fast charging stations in the operation area, all tours can be performed with BEV [6].

With regards to WTW emissions, FCEV have a small advantage over BEV when considering current electricity and hydrogen mixes. However, this hydrogen mix cannot be scaled arbitrarily, since about half of the hydrogen is a by-product from chemical processes, which in all likelihood will not be expanded by an increased demand for hydrogen. Since all of the hydrogen produced today is already absorbed by the market (especially the chemical industry), it can be expected that an increase in consumption by FCEV in the transportation sector would require new generation pathways. Therefore, we have performed the sensitivity analysis where the hydrogen is generated from current electricity. This leads to a high increase in WTW emissions even compared to ICEV. The effect would be similar for hydrogen produced entirely from fossil resources. It is therefore obvious that a positive effect in terms of WTW emissions can only be achieved by hydrogen from renewable sources, as the case FCEV100 shows. However, the achievable savings from directly using the renewable electricity in BEV are significantly higher as shown in the case BEV100.

In this study, the investigation of GHG emissions is only related to the energy consumption of the fleets. Thus, the environmental impacts of production, end of life, infrastructure and maintenance are out of scope. For a complete evaluation of the environmental impacts per vehicle fleet, a complete life cycle assessment Life Cycle Assessment (LCA) would be necessary. However, since commercial vehicles have a substantial higher lifetime mileage than passenger cars, the production and recycling emissions account for a smaller proportion of the complete life cycle emissions. In terms of energy consumption, the FCEV160 case is competitive with the ICEV case. However, the primary energy demand of $\mathrm{BEV}$ is preferable in all cases for the truck fleet of urban freight transport, since with both, the current electricity mix of Germany and the renewable electricity mix BEV have a smaller primary energy demand than FCEV and ICEV.

\section{Conclusion and outlook}

This study examines battery electric and fuel cell electric drive technologies with the objective to investigate their decarbonization effects on urban freight transport. ICEVs operated with diesel provided the base case. The food retailing in Berlin serves as a use case. Considering today's technology and fuel prices, a transition from ICEVs to BEVs would increase costs by $23 \%$. A change to FCEV has more than twice the increase with $57 \%$. In the considered future cases with lower fuel and technology prices $\mathrm{BEVs}$ are $17 \%$ higher compared to the base case. The transition to FCEVs is with $22 \%$ higher costs compared to the base case, still more expensive than BEV but the difference is smaller. When the transition to locally emission free trucks is considered today and today's electricity and hydrogen mixes should be used, FCEVs hold the potential to reduce GHG emissions by $33 \%$. This way, they outperform BEV, which would only achieve a reduction of $25 \%$ compared to the base case. However, as previously shown, this effect cannot be scaled up, since these savings are based on the fact that a large part of the hydrogen is a by-product. As soon as more hydrogen has to be produced from today's electricity or fossil fuels, the advantage of the technology becomes smaller and at some point turns into a disadvantage.

When more renewable energy is taken into account, the superiority of $\mathrm{BEV}$ is indisputable. If $100 \%$ renewables are considered, the savings potential of BEVs is with $92 \%$ significantly higher than that of FCEVs with $73 \%$. The analysis of the primary energy demand shows 
that with Germany's electricity mix of 2019 11\% less primary energy would be used when deploying BEVs. For the exclusive use of renewables, this value rises to $53 \%$. FCEVs on the other hand cause a 9\% increase in primary energy demand today and $60 \%$ more with renewable hydrogen. The range advantage of FCEVs shows to have no importance due to short delivery routes in this urban use case. To make FCEVs more competitive, the price of hydrogen has to decrease, which may result from economies of scale when demand for hydrogen rises. In further studies on the decarbonization of urban freight traffic, a mixed fleet composition of BEVs and FCEVs should be considered. The BEVs' batteries could be designed for short delivery routes, which would result in lower costs due to a smaller battery size. FCEVs can be used to cover the long delivery distances. Prospective research should also investigate $\mathrm{FC}$ and $\mathrm{BE}$ trucks for rural freight transport. Here, the range advantage of FCEVs could be the game changer for the decarbonization of freight transport. The option of producing hydrogen using PtG plants with surplus regenerative electricity for FCEVs makes sense from an energy utilization point of view. Depending on the configuration and purpose of the PtG plant, the produced hydrogen can be converted into electricity or transported to filling stations. With regard to primary energy demand, the question arises as to which of the WTW paths is most efficient for BEVs or for FCEVs. This issue may be the subject of further studies. To better assess the environmental impact of the two technologies, it would be interesting to conduct a full LCA that considers the production, operation and disposal of the vehicle fleets in addition to the WTW emissions. The result of this study is that FCEVs can outperform BEVs in terms of GHG emissions when considering today's hydrogen production and a very small fleet of FCEVs. But in all other considered categories and most importantly when assuming increasing shares of renewable energy, BEVs are the preferred technology choice for urban freight transport. According to our results BEVs are cheaper in total operation cost, reduce the primary energy demand and with rising shares of renewable energies in the grid, they have a higher potential to lower GHG emissions compared to FCEV.

\section{Authors' contributions}

All authors read and approved the final manuscript.

\section{Funding}

Open Access funding enabled and organized by Projekt DEAL. This work was funded by the Deutsche Forschungsgemeinschaft (DFG, German Research Foundation) - project number: 398051144.

Availability of data and materials

Not applicable.

\section{Author details}

${ }^{1}$ Chair of Methods for Product Development and Mechatronics, Technische Universität Berlin, Straße des 17. Juni 135, 10623 Berlin, Germany. ${ }^{2}$ Chair of Transport Systems Planning and Transport Telematics, Technische Universität Berlin, Straße des 17. Juni 135, 10623 Berlin, Germany.

Received: 19 May 2021 Accepted: 19 January 2022

Published online: 04 February 2022

References

1. BMU, Arbeitsgruppe IK III 1: Klimaschutz in Zahlen: Fakten, Trends und Impulse deutscher Klimapolitik.

2. Göhlich, D., Nagel, K., Syré, A. M., Grahle, A., Martins-Turner, K., Ewert, R., Miranda Jahn, R., \& Jefferies, D. (2021). Integrated approach for the assessment of strategies for the decarbonization of urban traffic. Sustainability, 13(2), 839. https://doi.org/10.3390/su13020839

3. Göhlich, D., Raab, A.F. (Eds.): (2021). Mobility2Grid - Sektorenübergreifende Energie- und Verkehrswende, 1. auflage 2021 edn. Energie- und Mobilitätssysteme der Zukunft. Springer Berlin and Springer Vieweg, Berlin.

4. Bundesministerium für Umwelt, Naturschutz und nukleare Sicherheit: Klimaschutzbericht 2019. https://www.bmu.de/download/klimaschut zbericht-2019/.

5. Robinius, M., Linßen, J., Grube, T., Reuß, M., Stenzel, P., Syranidis, K., Kuckertz, P., \& Stolten, D. Comparative analysis of infrastructures: Hydrogen fueling and electric charging of vehicles.

6. Miranda Jahn, R., Syré, A.M., Grahle, A., Martins-Turner, K., \& Göhlich, D. Methodology for determining charging strategies for freight traffic vehicles based on traffic simulation results. https://doi.org/10.14279/depos itonce-10977.

7. FuelCellWorks: Mitsubishi Fuso Presents its First Fuel Cell Concept Truck "Vision F-Cell" at Tokyo Motor Show 2019 (26.08.2020). https://fuelcellsw orks.com/news/mitsubishi-fuso-presents-its-first-fuel-cell-concept-truckvision-f-cell-at-tokyo-motor-show-2019/ Accessed 26.08.2020

8. Prandi, R. (2020). The Nikola Tre Lands in Europe. https://dieselprogress. com/nikola-tre-landed-in-europe-29701/ Accessed May 28, 2020.

9. Gnann, T., Patrick Plötz, P., Wietschel, M., \& Kühn, A. (2017). How to decarbonise heavy road transport. Accessed November 16, 2020

10. Gangloff, J.e.a. (2016). Design space assessment of hydrogen storage onboard medium and heavy duty fuel cell electric trucks. In ASME 201614 th international conference on fuel cell science, engineering and technology.

11. Elgowainy, A., \& Reddi, K. (2017). Hydrogen refueling analysis of heavyduty fuel cell vehicle fleet (8.6.2017)

12. EnergieArgentur.NRW: Brennstoffzelle \& Wasserstoff - Brennstoffzelle und Wasserstoff, Elektromobilität: Erzeugung (13-August-2020). https://www. energieagentur.nrw/brennstoffzelle/brennstoffzelle-wasserstoff-elekt romobilitaet/erzeugung

13. H2 MOBILITY: Netzausbau live (14-August-2020). https://h2.live/

14. González Palencia, J. C., Araki, M., \& Shiga, S. (2017). Energy consumption and $\mathrm{CO} 2$ emissions reduction potential of electric-drive vehicle diffusion in a road freight vehicle fleet. Energy Procedia, 142, 2936-2941. https://doi. org/10.1016/j.egypro.2017.12.420

15. Hammond, W., Axsen, J., \& Kjeang, E. (2020). How to slash greenhouse gas emissions in the freight sector: Policy insights from a technologyadoption model of Canada. Energy Policy, 137, 111093. https://doi.org/10. 1016/j.enpol.2019.111093

16. den Boer, E., Aarnink, S., Kleiner, F., \& Pagenkopf, J. Zero emissions trucks: An overview of state-of-the-art technologies and their potential

17. Kreyenberg, D., Lischke, A., Bergk, F., Duennebeil, F., Heidt, C., Knörr, W., Raksha, T., Schmidt, P., Weindorf, W., Naumann, K., Majer, S., \& MüllerLanger, F. Erneuerbare Energien im Verkehr: Potenziale und Entwicklungsperspektiven verschiedener erneuerbarer Energieträger und Energieverbrauch der Verkehrsträger, Berlin

18. Yazdanie, M., Noembrini, F., Dossetto, L., \& Boulouchos, K. (2014). A comparative analysis of well-to-wheel primary energy demand and greenhouse gas emissions for the operation of alternative and conventional vehicles in switzerland, considering various energy carrier production 
pathways. Journal of Power Sources, 249, 333-348. https://doi.org/10 1016/j.jpowsour.2013.10.043

19. Lombardi, S., Tribioli, L., Guandalini, G., \& lora, P. (2020). Energy performance and well-to-wheel analysis of different powertrain solutions for freight transportation. International Journal of Hydrogen Energy, 45(22), 12535-12554. https://doi.org/10.1016/j.ijhydene.2020.02.181

20. Lee, D.-Y., Elgowainy, A., Kotz, A., Vijayagopal, R., \& Marcinkoski, J. (2018). Life-cycle implications of hydrogen fuel cell electric vehicle technology for medium- and heavy-duty trucks. Journal of Power Sources, 393, 217-229. https://doi.org/10.1016/j.jpowsour.2018.05.012

21. Bishop, J. D. K., Axon, C. J., Banister, D., Bonilla, D., Tran, M., \& McCulloch M. D. (2011). Using non-parametric statistics to identify the best pathway for supplying hydrogen as a road transport fuel. International Journal of Hydrogen Energy, 36(15), 9382-9395. https://doi.org/10.1016/j.ijhydene. 2011.04.173

22. Burkhardt, J., Patyk, A., Tanguy, P., \& Retzke, C. (2016). Hydrogen mobility from wind energy —A life cycle assessment focusing on the fuel supply. Applied Energy, 181, 54-64. https://doi.org/10.1016/j.apenergy.2016.07. 104

23. Cetinkaya, E., Dincer, I., \& Naterer, G. F. (2012). Life cycle assessment of various hydrogen production methods. International Journal of Hydrogen Energy, 37(3), 2071-2080. https://doi.org/10.1016/j.ijhydene.2011.10.064

24. Djomo, S. N., \& Blumberga, D. (2011). Comparative life cycle assessment of three biohydrogen pathways. Bioresource Technology, 102(3), 2684-2694. https://doi.org/10.1016/j.biortech.2010.10.139

25. Rezaei, M., Mostafaeipour, A., Qolipour, M., \& Momeni, M. (2019). Energy supply for water electrolysis systems using wind and solar energy to produce hydrogen: A case study of Iran. Frontiers in Energy, 13(3), 539-550 https://doi.org/10.1007/s11708-019-0635-x

26. Yadav, D., \& Banerjee, R. (2020). Net energy and carbon footprint analysis of solar hydrogen production from the high-temperature electrolysis process. Applied Energy, 262, 114503. https://doi.org/10.1016/j.apenergy. 2020.114503

27. Danebergs, J. (2019). Techno-economic study of hydrogen as a heavyduty truck fuel: A case study on the transport corridor Oslo-Trondheim. Master of science thesis, KTH Industrial Engineering and Management, STOCKHOLM (September 16/2019)

28. Hall, D., \& Lutsey, N. Estimating the infrastructure needs and costs for the launch of zero-emission trucks.

29. McKinsey \& Company: A portfolio of power-trains for Europe: a factbased analysis: The role of Battery Electric Vehicles, Plug-in Hybrids and Fuel Cell Electric Vehicles.

30. Hülsmann, F., Mottschall, M., Hacker, F., \& Kasten, P. Konventionelle und alternative Fahrzeugtechnologien bei Pkw und schweren Nutzfahrzeugen-Potenziale zur Minderung des Energieverbrauchs bis 2050

31. Sim, K., Vijayagopal, R., Kim, N., \& Rousseau, A. (2019). Optimization of component sizing for a fuel cell-powered truck to minimize ownership cost. Energies, 12(6), 1125. https://doi.org/10.3390/en12061125

32. Zhao, H., Wang, Q., Fulton, L., Jaller, M., \& Burke, A. A Comparison of Zero-Emission Highway Trucking Technologies. University of California, Institute of Transportation Studies. https://doi.org/10.7922/G2FQ9TS7

33. Liu, N., Xie, F., Lin, Z., \& Jin, M. (2019). Evaluating national hydrogen refueling infrastructure requirement and economic competitiveness of fuel cell electric long-haul trucks. Mitigation and Adaptation Strategies for Global Change. https://doi.org/10.1007/s11027-019-09896-z.

34. Kovač, A., Marciuš, D., \& Budin, L. (2019). Solar hydrogen production via alkaline water electrolysis. International Journal of Hydrogen Energy, 44(20), 9841-9848. https://doi.org/10.1016/j.ijhydene.2018.11.007

35. Martins-Turner, K., Grahle, A., Nagel, Kai, \& Göhlich, D. (2020). Electrification of urban freight transport-A case study of the food retailing industry (pp. 1-7). Elsevier.

36. jsprit: (13.08.2020). https://github.com/graphhopper/jsprit

37. Schröder, S., \& Liedtke, G. Modeling and analyzing the effects of differentiated urban freight measures-A case study of the food retailing industry, Washington, D.C.

38. MATSim: Multi-Agent Transport Simulation (16.11.2020). https://matsim. org/, https://github.com/matsim-org/matsim-libs.

39. Open Berlin Scenario (16.11.2020). https://github.com/matsim-scenarios/ matsim-berlin

40. Geissdörfer, K., Gleich, R., \&Wald, A. (2009). Standardisierungspotentiale lebenszyklusbasierter modelle des strategischen kostenmanagements.
Zeitschrift für Betriebswirtschaft, 79(6), 693-715. https://doi.org/10.1007/ s11573-009-0256-7

41. PTV, TCl, \& Mann, H.U. Methodenhandbuch zum bundesverkehrswegeplan 2030

42. Eurotransport. (2018). Lastauto Omnibus Katalog 2018. Fahrzeugkosten

43. Wernet, G., Bauer, C., Steubing, B., Reinhard, J., Moreno-Ruiz, E., \& Weidema, B. (2016). The Ecoinvent database version 3 (Part I): Overview and methodology. The International Journal of Life Cycle Assessment, 21(9), 1218-1230. https://doi.org/10.1007/s11367-016-1087-8

44. Edwards, R.e.a. Well-to-tank Report Version 4.a JEC Well-to-wheels analysis: well-to-wheels analysis of future automotive fuels and powertrains in the European context

45. DIN Deutsches Institut für Normung e. V:: Methode zur Berechnung und Deklaration des Energieverbrauchs und der Treibhausgasemissionen bei Transportdienstleistungen (Güter- und Personenverkehr) (März 2013)

46. The European Parliament and The Council: amending Council Directive 96/53/EC laying down for certain road vehicles circulating within the Community the maximum authorised dimensions in national and international traffic and the maximum authorised weights in international traffic: DIRECTIVE (EU) 2015/719 (2015)

47. Scania: Norwegian wholesaler ASKO puts hydrogen powered fuel cell electric Scania trucks on the road (24.04.2020). https://www.scania.com/ group/en/home/newsroom/news/2020/norwegian-wholesaler-askoputs-hydrogen-powered-fuel-cell-electric-scania-trucks-on-the-road. html. Accessed April 24, 2020

48. Kurzweil, P. (2016). Brennstoffzellentechnik. Springer Fachmedien Wiesbaden, Wiesbaden. https://doi.org/10.1007/978-3-658-14935-2

49. Hunter, C., \& Penev, M. Market segmentation analysis of medium and heavy duty trucks with a fuel cell emphasis.

50. DIN Deutsches Institut für Normung e. V:: Kraftstoffe - Dieselkraftstoff: Anforderungen und Prüfverfahren (Oktober 2017)

51. Fraunhofer-Institut-ISE: Öffentliche Nettostromerzeugung in Deutschland im Jahr 2019 (2019). https://www.ise.fraunhofer.de/content/dam/ise/de/ documents/news/2019/Stromerzeugung_2019_2.pdf Accessed May 05, 2021

52. Wietschel, M., Kühnbach, M., \& Rüdiger, D. (2019). Die aktuelle treibhausgasemissionsbilanz von elektrofahrzeugen in deutschland: Working paper sustainability and innovation. Technical Report

53. Milanzi, S., Spiller, C., Grosse, B., Hermann, L., Kochems, J., \& Müller-Kirchenbauer, J. Technischer Stand und Flexibilität des Power-to-Gas-Verfahrens. https://www.er.tu-berlin.de/fileadmin/a38331300/Dateien/Techn ischer_Stand_und_Flexibilit\%C3\%A4t_des_Power-to-Gas-Verfahrens.pdf. Berlin

54. van Wijk, A., \& Wouters, F. Hydrogen: The Bridge between Africa and Europe.

55. Exchange Rates UK: Euro to Norwegian Krone Spot Exchange Rates for 2018 (15-August-2020). https://www.exchangerates.org.uk/EUR-NOKspot-exchange-rates-history-2018.html.

\section{Publisher's Note}

Springer Nature remains neutral with regard to jurisdictional claims in published maps and institutional affiliations. 